\title{
Nematicidal and fertilizing effects of chicken manure, fresh and composted olive mill wastes on organic melon
}

\author{
E. A. ABDEL-DAYEM ${ }^{1}$, F. ERRIQUENS ${ }^{2}$, V. VERRASTRO ${ }^{2}$, N. SASANELLI ${ }^{3 *}$, D. MONDELLII ${ }^{4}$, C. COCOZZA ${ }^{4}$ \\ ${ }^{1}$ Department of Vegetable Crops, Faculty of Agriculture, Cairo University, Giza, Egypt, 12613, ${ }^{2}$ International Centre \\ for Advanced Mediterranean Agronomic Studies, Via Ceglie, 9, 70010 Valenzano, Bari, Italy, ${ }^{3 *}$ Istituto per la \\ Protezione delle Piante, Consiglio Nazionale delle Ricerche, Via Amendola, 122/D, 70126 Bari, Italy, \\ E-mail: n.sasanelli@ba.ipp.cnr.it; ${ }^{4}$ Dipartimento di Biologia e Chimica Agro-Forestale ed Ambientale, Università \\ degli Studi di Bari “A. Moro”, Via Amendola, 165/A, 70126 Bari, Italy
}

\section{Summary}

The fertilizing and nematicidal effects of three organic amendments were evaluated in a pot experiment on melon plants infested by the root-knot nematode Meloidogyne incognita. A soil artificially infested with 4 eggs and juveniles/ml soil of the nematode was amended with: a) virgin olive pomace (VOP); b) composted olive pomace (COP); c) chicken manure based fertilizer (CM) and d) chicken manure based fertilizer combined with the biological control agent Paecilomyces lilacinus strain 251, brand name BioAct WG (CMB). VOP was applied at doses of 11 (VOP-A), 22 (VOP-B) and $44 \mathrm{t} /$ ha (VOP-C); COP at 4.5 (COP-A), 9 (COP-B) and 18 t/ha (COP-C); CM at 3 t/ha and $\mathrm{CMB}$ at $3 \mathrm{t} / \mathrm{ha}$ combined with $4 \mathrm{~kg} / \mathrm{ha}$ of BioAct WG. Untreated soil was used as control. The treatments $\mathrm{CM}$, CMB, VOP-B and COP-B were established on the basis of $\mathrm{N}$ requirement of melon plants $(120 \mathrm{~kg} / \mathrm{ha})$ taking into account soil and amendments $\mathrm{N}$ availability. Two weeks later amendment application and nematode inoculation, the soil was poured in 4.81 clay pots which were arranged in a greenhouse according to a randomized block design with ten replications for each treatment. A one-month old melon seedling (cv. Galia) was transplanted in each pot and organic farming management practices were used during the growing period. At the end of the experiment, 60 days after transplant, plants were uprooted and height, fresh and dry shoot and root weights were recorded. Root gall index, on the roots, caused by the nematode attack, was estimated according to a 0-5 scale. Final nematode population density and reproduction rate were also calculated for each pot. All data were subjected to statistical analysis of variance (ANOVA) and means compared according to Least Significant Difference's Test. Nematode population and root infestation were significantly suppressed by the addition of all amendments, compared to untreated control. However, CM and CMB resulted in a total more suppressive effect and in a significantly higher plant growth in comparison to all the other treatments. A significant correlation was found between root gall index and eggs and juveniles/g root and final nematode population density. No signifycant correlations were found between nematological parameters or plant growth parameters and amendment doses.

Keywords: Meloidogyne incognita; nematode control; composts; $\mathrm{N}$ requirement

\section{Introduction}

Root-knot nematodes Meloidogyne spp. are important plant parasites that can cause severe economic yield losses to numerous agricultural crops including vegetables (Sasanelli, 1994). The impact of these species is enhanced by their wide host ranges of more than 5,000 plant species belonging to different botanical families (Trudgill \& Blok, 2001). Generally, in conventional farming systems, these plant parasitic nematodes can be managed by the use of chemical nematicides or cultural practices (resistant cultivars and crop rotation) (Mai, 1985). However, root-knot nematode resistant varieties are available only for a limited number of vegetable crops and crop rotation is often difficult because of the wide host range of Meloidogyne spp. (Taylor \& Sasser, 1978). Moreover, the range of effective chemical products is limited, they are expensive, and their use on agricultural crops has been deeply restricted and revised by the recent European Legislation because of they have generally a negative impact on the environment and on the general public health (Reg. EC 396/2005, 1095/2007, 33/2008, 299/2008 and 1107/2009).

Several studies have been carried out to evaluate the effectiveness of control strategies at low environmental impact alternative to chemicals. A wide range of options was considered: amendments, biofumigations, crop rotation, grafting, green manures, mycorrhization, resistant cultivars 
(Gamliel et al., 2000; Sasanelli et al., 2002; Nico et al., 2004; Castillo et al., 2006; D’Addabbo et al., 2011; Renčo et al., 2007; 2009; 2011), soil solarization, ozone and steam applications (Sasanelli \& Greco, 2000; Tamietti \& Valentino, 2000; Tjamos et al., 2000; Ciccarese et al., 2008), biocidal plants or natural byproducts (Gommers, 1981; Grainge \& Ahmed, 1988; Sasanelli \& D'Addabbo, 1993; Sasanelli et al., 2007, 2009; Maistrello et al., 2010; Renčo et al., 2012) and biological control agents especially fungi and bacteria (Vannacci \& Gullino, 2000; Sasanelli et al., 2008).

Soil amendments, commonly used in organic farming, are effective in the management of several soil borne plant pathogens and phytoparasitic nematodes (Nico et al., 2004) and at the same time can improve soil fertility as well as productivity and quality of plant products (Bulluck et al., 2002; Rivera \& Aballay, 2008). In particular, in the Mediterranean countries, in the areas of cultivation of olive, the disposal of olive mill wastes represents a serious environmental problem as large amounts of these materials are produced in a short period every year. Incorporation of these materials into the soil may represent a possible solution to the problem of their disposal and in addition could result as an important resource of nitrogen, phosphorus, calcium and other elements as zinc, copper, magnesium essential to plant growth (Tester, 1990).

Various mechanisms are involved in the suppressive action among which the development of nematode natural enemies and the release of toxic compounds were found to be the most relevant (Stirling, 1991; Abawi \& Thurston, 1994; Oka et al., 2000). For plant-parasitic nematodes, the effectiveness of suppression varies depending from nematode species, type of amendment and amendment dose (Nico et al., 2004). According to Kaplan and Noe (1993) the use of the optimal amendment rate seems to be of primary importance indicating that the nematicidal activity is regulated by dose-response functions.

Although various organic amendments can have diverse effects on soil properties and nematode communities (Nahar et al., 2006; Hu \& Qi, 2010), all amendments tend to increase availability of plant nutrients, microbial biomass and bacterivore and fungivore nematodes (Briar et al., 2007). Chicken manure is also known to be effective in the control of root knot nematodes (Akhtar, 1997; Lopez-Pérez et al., 2005; Oka et al., 2000; D'Addabbo et al., 2003) and the mode of action is thought to be based on the release of toxic levels of ammonium, although alterations in soil structure, the stimulation of antagonistic organisms, and the increase of plant tolerance also may play a role (Oka et al., 2000; Lopez-Pérez et al., 2005).

Therefore, a pot experiment was carried out to compare the nematicidal and fertilizing effects of different amendments on organic melon. In particular virgin olive pomace and composted olive pomace were used at 3 different doses and compared to a chicken manure based commercial fertilizer in the presence and absence of the biological control agent Paecilomices lilacinus strain 251.

The purpose was to compare the effectiveness of different 260 amendments and to establish for each of them the most suitable dose for nematode control and plant growth.

\section{Materials and methods}

The pot experiment was carried out at the Mediterranean Agronomic Institute of Bari (MAIB) ( $41^{\circ} .0539$ North; $16^{\circ} .8773$ East Greenwich) from May to July 2009. Treatments with soil amendments were established on the basis of $\mathrm{N}$ requirement of melon plants $(120 \mathrm{~kg} / \mathrm{ha})$ taking into account soil and amendments $\mathrm{N}$ availability (Rodriguez et al., 2005).

\section{Preparation of nematode inoculum}

An Italian population of Meloidogyne incognita (Kofoid et White) Chitw. was reared for two months on tomato (Solanum lycopersicum L.) cv. Rutgers in a glasshouse at $25 \pm 2$ ${ }^{\circ} \mathrm{C}$. When large mature egg masses were formed, tomato roots were finely chopped and eggs and juveniles were quantified by processing 6 root samples of $10 \mathrm{~g}$ each with $1 \%$ aqueous solution of $\mathrm{NaOCl}$ (Hussey \& Barker, 1973). The roots were then throughly mixed with $3 \mathrm{Kg}$ of steam sterilised sandy soil ( $\mathrm{pH} 7.1$; sand $>99 \%$; silt $<1 \%$; clay $<1 \%$ and organic matter $=0.73 \%$ ) and used as inoculum.

\section{Soil sampling and soil analysis}

Soil samples were collected in a naturally $M$. incognita infested field. Soil sampling followed a W scheme and 20 single samples were mixed to obtain a final composite sample for physical, chemical and nematological analysis. Each single sample was collected at $30 \mathrm{~cm}$ depth after the removal of weeds and the first $5 \mathrm{~cm}$ topsoil. Before amendment application the soil sample and amendments were analyzed for physico-chemical parameters to establish the optimal amendment application doses.

The dose of each organic amendment to apply was calculated taking into account i) soil nitrogen content; ii) the mineralization rate of soil organic matter (Stanford \& Smith, 1972); iii) N melon requirement according to the Italian good agricultural practice (Min. D. n. 86, 1999); iv) amendment $\mathrm{N}$ content; $\mathrm{v}$ ) the mineralization rate of each amendment in order to calculate the amount of $\mathrm{N}$ released by organic fertilizers during the growing cycle (Cabrera et al., 2005; Whitmore, 2007). The purpose was to calculate the amount of available $\mathrm{N}$ released by soil and amendment during the growing period to support melon growth. Considering the $\mathrm{N}$ potential rate of mineralization and length of the melon crop cycle, doses of amendments able to satisfy completely the melon $\mathrm{N}$ requirement were: $22 \mathrm{t} / \mathrm{ha}$ for VOP; $9 \mathrm{t} / \mathrm{ha}$ for COP and $3 \mathrm{t} / \mathrm{ha}$ for CM and CMB (on a dry weight base).

To evaluate the effect of applied dose on nematode suppression and on plant growth, the corresponding double and half doses for VOP and COP were used.

Soil sample was air dried, weighted and sieved $2 \mathrm{~mm}$. Stones and gravels were collected and weighted after washing and the fine earth fraction was used for chemical and physical analyses. Soil texture was determined by using the pipette method (Indorante et al., 1990). The tex- 
tural class of the soil was calculated using the USDA soil textural classification system. Soil $\mathrm{pH}$ was measured on a soil suspension, 1:2.5 soil to water ratio $(\mathrm{w} / \mathrm{v})$ and 1:2.5 soil to $\mathrm{CaCl}_{2} 1 \mathrm{M}$ solution ratio (w/v) using a $\mathrm{pH}$ meter Crison model Basic 20 and a glass electrode Crison 52-00 (Thomas, 1996). The soil salinity was assessed by the measurement of the electrical conductivity on an water extract 1:2(w/v) soil to water ratio using a Conductivity meter XS cond 510. The electrical conductivity (EC) was expressed in $\mathrm{dS} / \mathrm{m}$ at $25{ }^{\circ} \mathrm{C}$ (Rhoades, 1996). Organic carbon was determined by the Walkley-Black method and Organic Matter was calculated by multiplying Soil Organic Carbon by the factor 1.72 (Nelson \& Sommers, 1996). Total nitrogen was determined by the Kjeldahl method (Bremner, 1996). Inorganic nitrogen was extracted from soil by a $\mathrm{KCl} 2 \mathrm{M}$ solution using a soil to extractant ratio of 1:10 (w/v). Nitrates and ammonium were then analyzed on $50 \mathrm{ml}$ of the extract by steam distillation in the presence and absence of $0.2 \mathrm{~g}$ of Devarda alloy respectively (Bremner \& Keeney, 1965). Available phosphorus was determined colorimetrically by using the Ascorbic Acid Method (Olsen \& Sommers, 1982). Absorbance was measured at $650 \mathrm{~nm}$ by a spectrophotometer model Megatech SP 930. Total carbonate content was determined by the volumetric calcimeter method (Loeppert \& Suarez, 1996) and active calcium according to the Drouineau method (Drouineau, 1942). Exchangeable bases (Ca, Mg, K, Na) were extracted from soil by using a solution of Barium Chloride (100 g/l) and Triethanolamine $(22.5 \mathrm{ml} / \mathrm{l})$ at $\mathrm{pH}$ to 8.2. $\mathrm{Ca}, \mathrm{K}, \mathrm{Mg}$ and $\mathrm{Na}$ concentrations were estimated by mean of Inductively Couple Plasma Optical Emission Spectrometry (ICP-OES) using a Thermo Electron ICAP 6000 Series spectrometer (Gessa \& Ciavatta, 2000).

\section{Organic amendments analysis}

Olive compost (COP) was produced at MAIB using virgin olive pomace (VOP) derived from a two phase olive oil industry. Chicken manure (CM and $\mathrm{CMB}$ ) was the main raw material of a commercial fertilizer. Representative samples of each amendment were analyzed for physical and chemical parameters before their use as soil amendments. $\mathrm{pH}$ was determined on a sample suspension $(3: 50 \mathrm{w} / \mathrm{v}$ compost to water ratio) using a $\mathrm{pH}$ meter Crison model Basic 20 and a glass electrode Crison 52-00. Salinity was assessed by the measurement of electrical conductivity on an aqueous extract $(1: 10 \mathrm{w} / \mathrm{v}$ compost to water ratio) (Italian Official Methods for Fertilizer Analysis, 2002).

Organic matter was determined by difference between dry sample and ash content obtained by ignition at $550{ }^{\circ} \mathrm{C}$ till constant weight (US. TMECC, 1997). Organic Carbon was calculated according to the Italian Official Methods for Fertilizer Analysis (2002). Total nitrogen was analyzed by using the Kjeldahl method (US. TMECC, 1997).

Total phosphorus content was determined by using the Ascorbic Acid Method (Olsen \& Sommers, 1982) on the digested sample. Acid digestion was carried out on $0.5 \mathrm{~g}$ of dry and grinded sample using a microwave system (US. TMECC, 1997). Absorbance was measured at $650 \mathrm{~nm}$ by a spectrophotometer model Megatech SP 930. Concentration was reported on a sample dry weight basis determined at $105^{\circ} \mathrm{C}$.

The relative secondary, micro-nutrient and heavy metals content of the digestate were determined by mean of Inductively Couple Plasma Optical Emission Spectrometry (ICP-OES) using a Thermo Electron ICAP 6000 Series spectrometer. Concentration was reported on a sample dry weight basis determined at $105^{\circ} \mathrm{C}$ (US. TMECC, 1997).

Seed germination and root elongation tests were applied to ensure the absence of any toxic effect for plant growth. The test was performed using the modified Zucconi's method (Zucconi et al., 1981). Briefly, organic amendment samples were kept to $85 \%$ of humidity to obtain a water extract. The suspension was shaken for 2 hours, centrifuged, filtered on $0.45 \mu \mathrm{m}$ sieve and dilutions $1: 1(\mathrm{v} / \mathrm{v})$ and $3: 1(\mathrm{v} / \mathrm{v})$ extract to water ratios were prepared. One $\mathrm{ml}$ of each diluted extract was used to inoculate $9 \mathrm{~cm}$ diameter Petri dishes in which 10 seeds of Lepidium sativum L. were then placed. Five replicates for each treatment and a control with distilled water were used. Petri dishes were incubated at $23{ }^{\circ} \mathrm{C}$ for $48 \mathrm{~h}$ and the germination index (G.I.) was calculated according to the formula:

$$
G I(\%)=\frac{G c \times L c}{G t \times L t} \times 100
$$

in which Gc: average No. of germinated seeds for sample; Lc: average of root length for sample; Gt: average No. of germinated seeds in the control and Lt: average of root length in the control.

\section{Pot experiment}

The soil collected and analysed as previously described was throughly mixed and amended with: a) virgin olive pomace (VOP); b) composted olive pomace (COP); c) chicken manure based fertilizer (CM) and d) chicken manure based fertilizer combined with the biological control agent $P$. lilacinus strain 251 (commercial name BioAct WG, CMB). VOP was applied at doses of 11 (VOP-A), 22 (VOP-B) and $44 \mathrm{t} / \mathrm{ha}$ (VOP-C); COP at 4.5 (COP-A), 9 (COP-B) and $18 \mathrm{t} /$ ha (COP-C); CM at $3 \mathrm{t} /$ ha and CMB at 3 $\mathrm{t} /$ ha combined with $4 \mathrm{~kg} / \mathrm{ha}$ of BioAct WG. Untreated soil was used as control. Each amended soil was then throughly mixed with appropriate amounts of the inoculum to give a population density of 4 eggs and juveniles/ml soil and stored in big plastic containers for two weeks to allow juveniles emergence and to start mineralization phase of the applied composts. The same soil, before transplant, was subjected to nematological analysis to verify the true initial nematode population density at the time of transplantation $(P i=1$ eggs and juveniles $/ \mathrm{ml}$ soil $)$. The treated and infested soils were then used to fill 4.81 pots. One-month old melon (Cucumis melo L., subsp. melo, var. cantalupensis Nardin) seedling, cv. Galia, was transplanted in each pot. Pots were arranged on banches in a greenhouse according to a randomized block design with 10 replications per each treatment. During the experiment melon plants were maintained in the greenhouse randomizing the position of the blocks and at the same time repositioning each plant 
within a block every week, to avoid a block position effect and at the same time the factor position of the plant within the block. Plants received all the necessary maintenance.

Moreover, during the growing period chlorophyll content of melon plants was recorded 3 times using a chlorophyll meter (SPAD). Each value resulted from the average of four readings on two leaves. Soil temperature was recorded at 1 hour intervals from $28^{\text {th }}$ May to $28^{\text {th }}$ July 2009 using a special temperature recorded (Temp 1000 by Madge Tech). Two months later, at the end of the experiment, plants were uprooted from the soil and height, fresh and dry top and root weight, number of leaves and chlorophyll content were recorded. Root gall index (RGI) was estimated according to a $0-5$ scale, where $0=$ no galls; $1=1-2$ galls; $2=3-10$ galls; $3=11-30$ galls; $4=31-100$ galls and 5 $>100$ galls (Taylor \& Sasser, 1978). Soil nematode population density in each pot eas determined by processing $500 \mathrm{ml}$ soil by the Coolen's method (Coolen, 1979). Numbers of $M$. incognita eggs and second stage juveniles in roots were assessed by cutting up each root system into small pieces and further comminuting them in a blender, containing $1 \%$ aqueous solution of $\mathrm{NaOCl}$ for $20 \mathrm{sec}$ (Marull \& Pinochet, 1991). The water suspension was then sieved through a $250 \mu \mathrm{m}$ pore sieve put over a $5 \mu \mathrm{m}$ pore sieve. Nematodes and root debris gathered on the $5 \mu \mathrm{m}$ pore sieve were further processed by centrifuging at 2,000 rpm for five min in $400 \mathrm{ml}$ of a magnesium sulphate solu- tion of 1.16 specific gravity. Then eggs and juveniles in the water suspension were sieved through the $5 \mu \mathrm{m}$ pore sieve, sprayed with tap water to wash away the magnesium sulphate solution and collected in about $40-50 \mathrm{ml}$ water. Then they were counted and final nematode population density $(P f)$ in each pot was determined by summing nematodes recovered from soil and roots. The nematode reproduction factor $r$ was expressed as ratio between final and initial population density at time of transplant $(\mathrm{Pf} / \mathrm{Pi})$ of $M$. incognita.

Data from the experiment were subjected to analysis of variance (ANOVA) and means compared by Least Significant Difference's Test. All statistical analysis were performed using the PlotIT program. Table Curve program was used to analyze the relationships between different compost doses and nematological parameters of the rootknot nematode.

\section{Results and discussion}

Soil physical and chemical parameters

Physical and chemical soil parameters are shown in Table 1. Soil used in the pot trial was characterized by a silt-clay-loam texture according to the USDA soil textural classification system and modest resulted the amount of stones and gravels.

Soil reaction was slightly alkaline mainly due to the con-

Table 1. Physical and chemical characteristics of soil

\begin{tabular}{lcc}
\hline Parameter & Unit & Value \\
\hline Stones and Gravels $(\varnothing>2 \mathrm{~mm})$ & $\mathrm{g} / \mathrm{kg}$ & $22^{*}$ \\
Sand $(\varnothing<0.5 \mathrm{~mm})$ & $\mathrm{g} / \mathrm{kg}$ & 156 \\
Silt $(0.002 \mathrm{~mm}<\varnothing<0.5 \mathrm{~mm})$ & $\mathrm{g} / \mathrm{kg}$ & 563 \\
Clay $(\varnothing<0.002 \mathrm{~mm})$ & $\mathrm{g} / \mathrm{kg}$ & 281 \\
Textural Class $(\mathrm{USDA})$ & $/$ & Silty Clay Loam \\
$\mathrm{pH}(1: 2,5 \mathrm{H} 2 \mathrm{O})$ & $/$ & 8.0 \\
$\mathrm{pH}\left(1: 2,5 \mathrm{CaCl}_{2}\right)$ & $/$ & 7.3 \\
Electrical conductivity & $\mathrm{dS} / \mathrm{m}$ & 0.2 \\
$\left(1: 2 \mathrm{H}_{2} \mathrm{O}\right.$ at $\left.25^{\circ} \mathrm{C}\right)$ & $\mathrm{g} / \mathrm{kg}$ & 29.0 \\
Total Carbonate & $\mathrm{g} / \mathrm{kg}$ & 27.2 \\
Active Calcium & $\mathrm{g} / \mathrm{kg}$ & 12.7 \\
Organic Carbon & $\mathrm{g} / \mathrm{kg}$ & 1.3 \\
Total Nitrogen & $/$ & 10.1 \\
C/N & $\mathrm{g} / \mathrm{kg}$ & 23.8 \\
Available Phosphorus & $\mathrm{g} / \mathrm{kg}$ & 5556 \\
Exchangeable Calcium & $\mathrm{g} / \mathrm{kg}$ & 346 \\
Exchangeable Potassium & $\mathrm{g} / \mathrm{kg}$ & 244 \\
Exchangeable Magnesium & $\mathrm{g} / \mathrm{kg}$ & 90 \\
Exchangeable Sodium & $\mathrm{g} / \mathrm{kg}$ & 419 \\
Exchangeable $\mathrm{K}_{2} \mathrm{O}$ & $\mathrm{g} / \mathrm{kg}$ & 402 \\
Exchangeable MgO & $/$ & 13.8 \\
Ca/Mg & $/$ & 0.9 \\
$\mathrm{~K} / \mathrm{Mg}$ & & \\
\hline Each data is an average of four replications & & \\
\hline
\end{tabular}


tent of total carbonate and active calcium. According to electrical conductivity $(0.2 \mathrm{dS} / \mathrm{m})$ the soil can be defined non saline (salinity class $=0$ ). Organic carbon and total $\mathrm{N}$ content indicated a medium level of fertility. $\mathrm{C} / \mathrm{N}$ ratio indicated a good level of humification of organic matter (USDA, 1995; Ryan et al., 2001). Available phosphorus (P) content resulted low probably because the high calcium content that is responsible of the removal of phosphorus as insoluble calcium phosphates salts.

Among the exchangeable basis, the amount of $\mathrm{Ca}^{++}$resulted very high ( $90 \%$ of the sum of all the exchangeable basis), while the $\mathrm{Na}^{+}$content was low $(1.29 \%)$ and the concentration of $\mathrm{Mg}^{++}$and $\mathrm{K}^{+}$intermediate (USDA, 1995; Ryan et al., 2001). Finally the ratio $\mathrm{Ca} / \mathrm{Mg}$ and $\mathrm{K} / \mathrm{Mg}$ indicated the presence of competition in the uptake of $\mathrm{Mg}^{++}$ due to the high content of $\mathrm{Ca}^{++}$and $\mathrm{K}^{+}$(Ryan et al., 2001).

\section{Amendment physical and chemical parameters}

Physical and chemical properties of organic amendments used in the experiment are shown in Table 2. COP was characterized by a high organic $\mathrm{C}$ and $\mathrm{N}$ content while $\mathrm{C} / \mathrm{N}$ ratio (19.8) indicated an adequate level of stability and humification of the organic matter, being 20 the highest threshold for this parameter in stabilized organic amendments (Bernal et al., 2009; Min. D. n. 75/2010). Heavy metals content was lower than the limits established by the Italian Regulation (Min. D. n. 75/2010) and the germination index $(84.1 \%)$ indicated the absence of phytotoxicity (GI $>50 \%$ ) (Bernal et al., 1998; 2009) and a high level of maturity (GI > 80 \%) (US. TMECC, 1997; CCQC, 2001).
Analytical values indicated that compost organic matter mineralization in soil, and as consequence the availability of nutrients for plant growth, will not be altered neither by $\mathrm{NH}_{3}$ production that occurs in case of low $\mathrm{C} / \mathrm{N}$ ratio nor by deficiency of $\mathrm{N}$ that occurs in case of high $\mathrm{C}$ availability for microbial metabolism and low N supply (Senesi, 1989; Bernal et al., 2009).

Physical and chemical properties of VOP resulted in line with data reported by Roig et al. (2006). VOP showed a slightly acidic $\mathrm{pH}$, a high organic matter (OM) content but a low $\mathrm{N}$ one. As a consequence, $\mathrm{C} / \mathrm{N}$ ratio resulted very high $(\mathrm{C} / \mathrm{N}=53)$ as reported by other authors (Saviozzi et al., 2001; Roig et al., 2006; López-Piñeiro et al., 2008). These authors suggested the addition of nitrogen fertilisers together with VOP to avoid immobilization of soil mineral $\mathrm{N}$ and $\mathrm{P}$ and a general nutritional imbalance for plant growth. The same authors indicated VOP as a $\mathrm{K}$ rich fertilizer, but in our case the amount of $\mathrm{K}$ as well as of $\mathrm{P}$ resulted lower than most of data already published. The second problem often related to the use of VOP as soil amendment is the high polyphenols content that is associated with the phytotoxicity and antimicrobial properties of the residue (Cayuela et al., 2008). In our study, the germination index resulted higher than the limit of toxicity (GI > $50 \%$ ) (Bernal et al., 2009) but we cannot define the VOP used in the experiment as a mature or completely not phytotoxic amendment since a high level of maturity is assured by GI values greater than $80 \%$ (Iglesias-Jimenez \& PerezGarcia, 1992; CCQC, 2001; Bernal et al., 2009; Saidi et al., 2009). In the present study no nitrogen fertilizers were

Table 2. Physical and chemical characteristic of different organic amendments (virgin olive pomace, composted olive pomace and chicken manure)

\begin{tabular}{lcccc}
\hline Parameter & Unit & VOP & COP & CM \\
\hline Humidity & $\%$ & 53.5 & 61.4 & 9.0 \\
pH $\left(3: 50 \mathrm{H}_{2} \mathrm{O}\right)$ & & 5.6 & 9.4 & 6.9 \\
Organic Matter & $\mathrm{g} / \mathrm{kg}$ & 924.5 & 864.1 & 691.5 \\
Organic Carbon & $\mathrm{g} / \mathrm{kg}$ & 481.5 & 450.0 & 360.2 \\
Total Nitrogen & $\mathrm{g} / \mathrm{kg}$ & 9.1 & 22.8 & 63.9 \\
C/N & & 53.0 & 19.8 & 5.6 \\
Total $\mathrm{P}$ & $\mathrm{g} / \mathrm{kg}$ & 0.6 & 3.0 & 65.5 \\
Total $\mathrm{Cd}$ & $\mathrm{mg} / \mathrm{kg}$ & $<0.05$ & 0.06 & 3.4 \\
Total Cu & $\mathrm{mg} / \mathrm{kg}$ & 11.2 & 104.8 & 46.4 \\
Total $\mathrm{Mn}$ & $\mathrm{mg} / \mathrm{kg}$ & 70.9 & 73.8 & 275.8 \\
Total $\mathrm{Ni}$ & $\mathrm{mg} / \mathrm{kg}$ & 10.1 & 8.3 & 14.1 \\
Total $\mathrm{Pb}$ & $\mathrm{mg} / \mathrm{kg}$ & 4.7 & 2.5 & 0.5 \\
Total $\mathrm{Zn}$ & $\mathrm{mg} / \mathrm{kg}$ & 16.6 & 41.6 & 314.6 \\
Total $\mathrm{Ca}$ & $\mathrm{g} / \mathrm{kg}$ & 5.3 & 23.5 & 68.6 \\
Total K & $\mathrm{g} / \mathrm{kg}$ & 6.3 & 13.5 & 33.7 \\
Total $\mathrm{Mg}$ & $\mathrm{g} / \mathrm{kg}$ & 0.9 & 2.1 & 12.5 \\
Total $\mathrm{Na}$ & $\mathrm{g} / \mathrm{kg}$ & 0.4 & 5.0 \\
Total $\mathrm{Fe}$ & $\mathrm{g} / \mathrm{kg}$ & 2.8 & 2.1 & 2.7 \\
Total phenols & $\mathrm{mg} \mathrm{GA} / \mathrm{g}$ & 3.8 & 1 & $/$ \\
Germination index 50 & 62.3 & 84.1 & 1.2 \\
\hline
\end{tabular}

* Each data is an average of four replications 
Table 3. Effect of different amendments and doses on the growth of melon plants (cv. Galia) in soil infested by the root-knot nematode Meloidogyne incognita

\begin{tabular}{|c|c|c|c|c|c|c|c|c|c|c|c|}
\hline \multirow{3}{*}{$\begin{array}{l}\text { Treatment } \\
\text { VOP-A }\end{array}$} & \multirow{3}{*}{$\begin{array}{c}\begin{array}{c}\text { Dose } \\
\text { (dw) } \\
\text { (t/ha) }\end{array} \\
11\end{array}$} & \multicolumn{4}{|c|}{ Shoot weight (g) } & \multirow{2}{*}{\multicolumn{2}{|c|}{$\begin{array}{c}\text { Shoot length } \\
\text { (cm) }\end{array}$}} & \multirow{2}{*}{\multicolumn{2}{|c|}{$\mathbf{N}^{\circ}$ of leaves }} & \multirow{2}{*}{\multicolumn{2}{|c|}{$\begin{array}{c}\text { Root weight } \\
\text { (g) }\end{array}$}} \\
\hline & & \multicolumn{2}{|c|}{ fresh } & \multicolumn{2}{|c|}{ dry } & & & & & & \\
\hline & & $48.7^{*}$ & $\mathrm{~b}^{* *}$ & 6.8 & $\mathrm{~b}$ & 60 & $\mathrm{a}$ & 23 & $\mathrm{~b}$ & 15.0 & $\mathrm{a}$ \\
\hline VOP-B & 22 & 31.7 & $a b$ & 4.3 & $\mathrm{ab}$ & 61 & $\mathrm{a}$ & 16 & $\mathrm{a}$ & 12.4 & $\mathrm{a}$ \\
\hline VOP-C & 44 & 20.2 & $\mathrm{a}$ & 2.6 & $\mathrm{a}$ & 54 & $\mathrm{a}$ & 14 & $\mathrm{a}$ & 6.2 & $\mathrm{a}$ \\
\hline COP-A & 4.5 & 90.6 & $\mathrm{c}$ & 15.0 & $\mathrm{c}$ & 85 & $\mathrm{~b}$ & 30 & $\mathrm{c}$ & 15.7 & $\mathrm{a}$ \\
\hline COP-B & 9 & 95.7 & $\mathrm{~cd}$ & 15.6 & $\mathrm{~cd}$ & 125 & $\mathrm{c}$ & 39 & $\mathrm{~d}$ & 36.3 & $\mathrm{~b}$ \\
\hline $\mathrm{COP}-\mathrm{C}$ & 18 & 89.7 & $\mathrm{c}$ & 14.6 & $\mathrm{c}$ & 84 & $\mathrm{~b}$ & 33 & $\mathrm{c}$ & 20.6 & $\mathrm{ab}$ \\
\hline $\mathrm{CM}$ & 3 & 370.6 & e & 52.7 & $\mathrm{e}$ & 124 & $\mathrm{c}$ & 56 & $\mathrm{e}$ & 96.4 & c \\
\hline $\mathrm{CMB}$ & 3 & 398.6 & $\mathrm{f}$ & 57.4 & $\mathrm{f}$ & 133 & $\mathrm{c}$ & 58 & $\mathrm{e}$ & 88.5 & $\mathrm{c}$ \\
\hline $\begin{array}{c}\text { Control } \\
\text { (untreated) }\end{array}$ & --- & 118.6 & $\mathrm{~d}$ & 18.9 & $\mathrm{~d}$ & 96 & $\mathrm{~b}$ & 34 & $\mathrm{~cd}$ & 33.2 & $\mathrm{~b}$ \\
\hline
\end{tabular}

used in addition to VOP to avoid interference in the nematicide effect of the amendment. Our goals were to evaluate the nematode suppression capacity of VOP and COP as well as the ability of these amendments to support plant growth. Different doses were used to find the best solution for nematode control and plant growth.

$\mathrm{CM}$ could be considered an organic fertilizer rather than an amendment. It was characterised by a neutral $\mathrm{pH}$, a high $\mathrm{N}$ content and a low $\mathrm{C} / \mathrm{N}$ ratio. Also high resulted the content of $\mathrm{P}, \mathrm{Ca}, \mathrm{K}, \mathrm{Mg}$ that probably were quickly mineralized in soil considering the low $\mathrm{C} / \mathrm{N}$ ratio $(\mathrm{C} / \mathrm{N}=5.6)$ of this fertilizer.

The nematicidal activity of ammonia released during its mineralization greatly depends on environmental conditions, such as $\mathrm{pH}$, temperature and humidity. The slightly alkaline $\mathrm{pH}$ of the soil used, the high temperature and the frequent irrigations probably favoured the mineralization of $\mathrm{CM}$ organic matter and the release of $\mathrm{NH}_{3}$ in soil (Oka et al., 2000).

\section{Plant growth parameters and chlorophyll content}

Type and rates of amendments significantly affected plant growth and biomass compared to untreated control (Table 3). Plants amended with CM and CMB showed the highest values of plant growth and biomass in comparison to the other treatments $(P=0.05)$. However, $\mathrm{CM}$ and CMB treatments were not significantly different each other $(P=$ 0.05 ) for root weight, number of leaves and wine length indicating that $P$. lilacinus did not have any influence in plant nutrients uptake. VOP resulted the worst treatment for plant growth and among the different doses $11 \mathrm{t} / \mathrm{ha}$ showed the higher values for shoot and root weight, shoot length and number of leaves. As expected, data obtained confirm the phytotoxic effect of the amendment although seed germination and root elongation tests did not indicate a high level of toxicity (Table 3 ).

All COP treatments showed significantly lower values of shoot and root weights in comparison to untreated control $(P=0.05)$. No statistical differences were found among COP treatments and untreated control in the number of leaves and shoot length (Table 3). Only the treatment COP-B ( $9 \mathrm{t} / \mathrm{ha})$ produced a significantly higher number of leaves and shoot length in comparison to COP-A and COP$\mathrm{C}$ tretaments (Table 3 ).

As observed for plant growth parameters, $\mathrm{CM}$ and $\mathrm{CMB}$ treatments showed significantly higher chlorophyll content during the whole life cycle of melon plants with respect to untreated control, VOP and COP treatments $(P=0.05)$ (Table 4). Significantly lower values were recorded for VOP at all doses applied in comparison to all other treatments (COP, $\mathrm{CM}$ and $\mathrm{CMB}$ ). No differences in chlorophyll content were observed between COP treatments and untreated control indicating that the release of nutrients was probably lower than that was expected $(P=0.05)$ (Table 4$)$.

\section{Nematological parameters}

All treatments with soil amendments significantly reduced root gall index (RGI) of the nematode on roots in comparison to untreated control $(P=0.05)$ (Table 5). The lowest gall index (1.2) was recorded on the roots of the plants treated with $\mathrm{CMB}$, although no statistical difference was observed in comparison to CM treatment. Probably, $P$. lilacinus was not effective to improve significantly the reduction of RGI because of the fungus required a longer time to colonize the rhizosphere and/or the high amount of ammonium released by $\mathrm{CM}$ had a toxic effect not only on $M$. incognita but also on the antagonistic fungus. CM application, alone or in combination with $P$. lilacinus, resulted in a nematicidal action on the root-knot nematode population at rate of $3 \mathrm{t} / \mathrm{ha}$ lower than those previously reported in the literature (Rodriguez-Kabana, 1986; Kaplan \& Noe, 1993). No differences were observed in RGI among the different applied rates of VOP and COP treatments (Table 5). 
Table 4. Effect of different amendments (VOP, COP and CM) and their doses on chlorophyll content of leaves of melon plants (cv. Galia), infested with $M$. incognita, during the growing period

\begin{tabular}{|c|c|c|c|c|c|c|c|}
\hline \multirow{4}{*}{$\begin{array}{l}\text { Treatment } \\
\text { VOP-A }\end{array}$} & \multirow{4}{*}{$\begin{array}{c}\text { Dose (dw) } \\
\text { t/ha } \\
11\end{array}$} & \multicolumn{6}{|c|}{ Chlorophyll content (Spad unit) } \\
\hline & & \multirow{2}{*}{\multicolumn{2}{|c|}{ 13/06/2009 }} & \multicolumn{2}{|c|}{ Date } & \multirow{2}{*}{\multicolumn{2}{|c|}{ 19/07/2009 }} \\
\hline & & & & \multicolumn{2}{|c|}{$01 / 07 / 2009$} & & \\
\hline & & $25.3^{*}$ & $b^{* *}$ & 27.5 & $\mathrm{a}$ & 26.2 & $\mathrm{a}$ \\
\hline VOP-B & 22 & 18.2 & $\mathrm{a}$ & 27.4 & $\mathrm{a}$ & 26.9 & $\mathrm{a}$ \\
\hline VOP-C & 44 & 19.8 & $\mathrm{a}$ & 23.5 & $\mathrm{a}$ & 25.6 & a \\
\hline COP-A & 4.5 & 37.9 & $\mathrm{c}$ & 31.9 & $\mathrm{~b}$ & 35.0 & $\mathrm{~b}$ \\
\hline COP-B & 9 & 35.4 & $\mathrm{c}$ & 32.3 & $\mathrm{~b}$ & 32.4 & $\mathrm{~b}$ \\
\hline $\mathrm{COP}-\mathrm{C}$ & 18 & 34.4 & $\mathrm{c}$ & 34.8 & $\mathrm{~b}$ & 34.8 & b \\
\hline $\mathrm{CM}$ & 3 & 46.4 & $\mathrm{~d}$ & 46.2 & $\mathrm{c}$ & 45.7 & $\mathrm{c}$ \\
\hline $\mathrm{CMB}$ & 3 & 49.8 & d & 49.5 & $\mathrm{c}$ & 47.4 & $\mathrm{c}$ \\
\hline $\begin{array}{c}\text { Control } \\
\text { (untreated) }\end{array}$ & --- & 37.7 & $\mathrm{c}$ & 34.6 & $\mathrm{~b}$ & 32.3 & $\mathrm{~b}$ \\
\hline
\end{tabular}
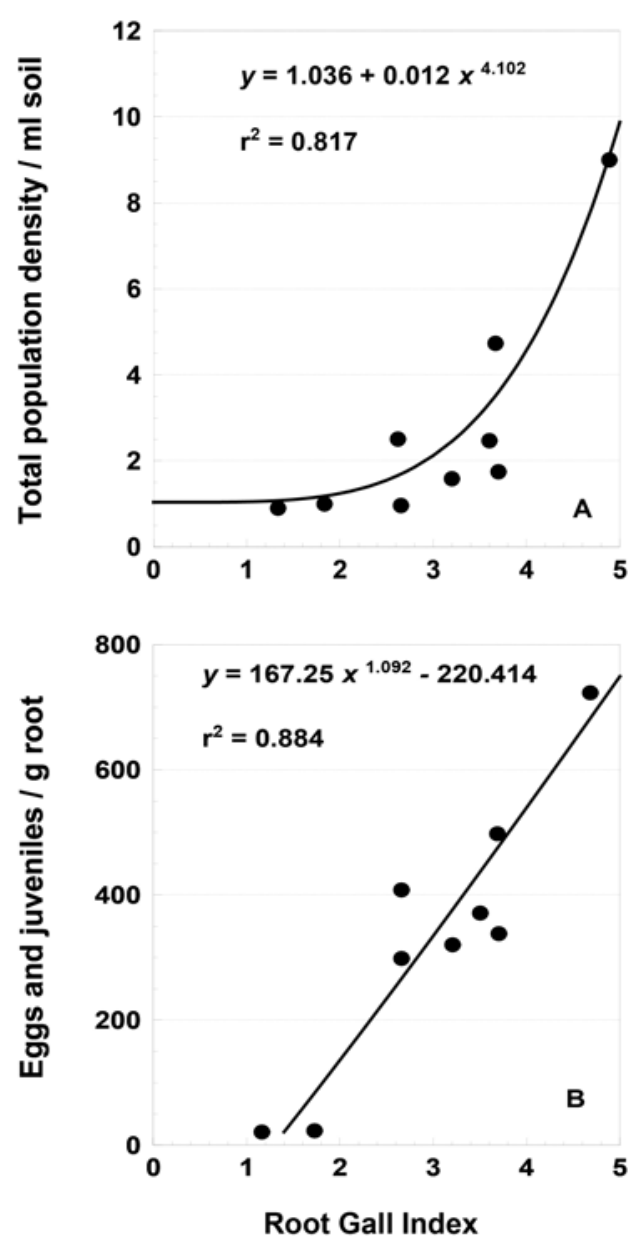

Fig. 1. Relationship between root gall index (RGI) observed on roots of melon plants infested with the root-knot nematode Meloidogyne incognita and nematode population density/ml soil (A) and eggs and juveniles/g root (B)

Number of eggs and second stage juveniles of the nematode and females per $g$ of $\operatorname{root}(P=0.05)$ were significantly reduced by all treatments with soil amendments in comparison to the untreated control (Table 5). The lowest numbers of eggs and juveniles per $\mathrm{g}$ of root were observed in $\mathrm{CM}$ and $\mathrm{CMB}$ treatments with no significant difference between them.

In VOP and COP treatments, the number of eggs and juveniels per $g$ root was significantly higher than that calculated in $\mathrm{CM}$ and $\mathrm{CMB}$ treatments and significantly lower than that evaluated in the untreated control. No statistical differences were observed among the different doses applied of VOP and COP amendments. The highest number of eggs and juveniles per $g$ of root was observed in the untreated control (751 eggs and juveniles/g root) (Table 5). Moreover, no significant differences were found in number of females/g root among the different amendments and the applied doses (Table 5).

These data confirm that all amendments incorporated into the soil were effective in nematode suppression and among them $\mathrm{CM}$ and $\mathrm{CMB}$ were the most effective. With regards to application doses, no differences in nematode control were observed indicating that, in the case of VOP application, the lowest dose can be used to minimize its phytotoxicity while, in the case of COP or $\mathrm{CM} / \mathrm{CMB}$ amendments, the dose can be calculated on the basis of the nutrient content and their mineralization rate.

All soil amendments strongly and significantly reduced soil nematode population density in comparison to untreated control $(P=0.05)$ (Table 5). No statistical differences were observed among the doses applied of VOP and COP with the exception of COP-B treatment. Moreover, these treatments were not significantly different from $\mathrm{CM}$ and CMB. The addition of $P$. lilacinus did not significantly reduce soil nematode population density in comparison to $\mathrm{CM}$. The reproduction rate $(P f / P i)$ showed the same trend of final soil nematode population density and it was rather low, especially in the untreated control, according to the high temperatures recorded during the experiment. Indeed, soil temperature ranged from $15.6{ }^{\circ} \mathrm{C}$ to $42.8^{\circ} \mathrm{C}$. Organic matter mineralization was probably influenced by soil 
Table 5. Effect of different amendments (VOP, COP and CM) and their doses on root gall index, eggs and juveniles and females/g root, final nematode population density $/ \mathrm{ml}$ soil and reproduction rate of melon plants (cv. Galia) infested with $M$. incognita

\begin{tabular}{|c|c|c|c|c|c|c|c|c|c|c|c|}
\hline \multirow[t]{2}{*}{ Treatment } & \multirow{2}{*}{$\begin{array}{l}\text { Dose } \\
\text { (dw) } \\
\text { (t/ha) }\end{array}$} & \multicolumn{2}{|c|}{$\begin{array}{l}\text { Root Gall } \\
\text { Index } \\
\text { (RGI) } \\
\end{array}$} & \multicolumn{4}{|c|}{ Nematodes/g root } & \multirow{2}{*}{\multicolumn{2}{|c|}{$\begin{array}{c}\text { Final nematode } \\
\text { population } \\
\text { density } \\
\begin{array}{c}\text { (Eggs and } \mathbf{J}_{2} / 10 \\
\text { ml soil) }\end{array} \\
\end{array}$}} & \multirow{2}{*}{\multicolumn{2}{|c|}{$\begin{array}{c}\text { Reproduction } \\
\text { rate } \\
(P f / P i)\end{array}$}} \\
\hline & & \multicolumn{2}{|c|}{ Scale (0-5) } & \multicolumn{2}{|c|}{ Eggs and $J_{2}$} & \multicolumn{2}{|c|}{ Females } & & & & \\
\hline VOP-A & 11 & $3.1^{*}$ & $\mathrm{c}^{* *}$ & 326 & $\mathrm{~b}$ & 0.94 & $\mathrm{a}$ & 15 & $\mathrm{a}$ & 1.5 & $\mathrm{a}$ \\
\hline VOP-B & 22 & 2.7 & $\mathrm{bc}$ & 315 & $\mathrm{~b}$ & 0.41 & $\mathrm{a}$ & 30 & $\mathrm{a}$ & 3.0 & $\mathrm{a}$ \\
\hline VOP-C & 44 & 2.7 & bc & 409 & $\mathrm{~b}$ & 1.43 & $\mathrm{a}$ & 13 & $\mathrm{a}$ & 1.3 & $\mathrm{a}$ \\
\hline COP-A & 4.5 & 3.5 & c & 385 & $\mathrm{~b}$ & 1.76 & $\mathrm{a}$ & 22 & $\mathrm{a}$ & 2.2 & $\mathrm{a}$ \\
\hline COP-B & 9 & 3.6 & $\mathrm{c}$ & 523 & bc & 1.20 & $\mathrm{a}$ & 54 & $\mathrm{~b}$ & 5.4 & $\mathrm{~b}$ \\
\hline COP-C & 18 & 3.6 & c & 344 & $\mathrm{~b}$ & 0.46 & $\mathrm{a}$ & 18 & $\mathrm{a}$ & 1.8 & $\mathrm{a}$ \\
\hline $\mathrm{CM}$ & 3 & 1.8 & $a b$ & 6 & $\mathrm{a}$ & 0.12 & $\mathrm{a}$ & 11 & $\mathrm{a}$ & 1.1 & $\mathrm{a}$ \\
\hline $\mathrm{CMB}$ & 3 & 1.2 & $\mathrm{a}$ & 7 & $\mathrm{a}$ & 0.03 & $\mathrm{a}$ & 9 & $\mathrm{a}$ & 0.9 & $\mathrm{a}$ \\
\hline $\begin{array}{c}\text { Untreated } \\
\text { control }\end{array}$ & --- & 4.9 & $\mathrm{~d}$ & 751 & $\mathrm{c}$ & 4.00 & $\mathrm{~b}$ & 87 & c & 8.7 & $\mathrm{c}$ \\
\hline
\end{tabular}

temperature being nitrification severely restricted and eventually stopped by temperature above $37^{\circ} \mathrm{C}$ while the optimum range of temperature for $\mathrm{C}$-mineralization is supposed to be between 25 and $45^{\circ} \mathrm{C}$ (De Neve et al., 1996).

Based on this results, indipendently from the amendment, significant positive correlations were found in the relationship between root gall index and total nematode density into the soil (Fig. 1A) and eggs and juveniles/g root (Fig. 1B) of $M$. incognita. The equations reasonably explain the above relationships, as indicated by the high values of the correlation coefficients $(r)$.

\section{Conclusions}

According to the obtained biometric and nematological data (Table 4 and 5) CM and CMB resulted the most effective treatments in the root-knot nematode control and melon plant growth. The reason could be due to the higher availability of nitrogen and phosphours in $\mathrm{CM}$ and $\mathrm{CMB}$ treatments in comparison to VOP and COP treatments. The presence of a higher content of available $\mathrm{N}$ might have affected and improved plant growth with a greater plant resistance to nematode attacks. So, plant growth enhanced by $\mathrm{CM}$ and $\mathrm{CMB}$ treatments could be due to the combination of the suppressive effect on the root-knot nematode with a direct fertilizing effect on melon plants, as observed in previous trials on tomato (D'Addabbo et al., 2003).

Results from this experiment confirm the suppressivity of VOP, COP and CM on M. incognita, previously reported in other trials (D'Addabbo \& Sasanelli, 1996; D'Addabbo et al., 2000) in which the suppressive action was related to soil amendments rates.

Phytotoxic effect observed in VOP amended pots, as previously reported (Rodriguez-Kabana et al., 1992; 1995), could possibly be explained by the short interval between
VOP incorporation and transplanting (only 2 weeks), which probably did not allow the degradation of phytotoxic compounds.

The suppressive effect on nematode population was not significantly increased in CM by the addition of $P$. lilacinus, showing a greater and direct suppressive effect of chicken manure in comparison to the biological control agent, which require time to colonize the rhizosphere.

Also soil temperature recorded, higher than $40{ }^{\circ} \mathrm{C}$, might have influenced the suppressive nematode effect of the different amendments tested, as previously reported by Lopez-Perez et al. (2005) for the nematicidal efficacy on M. incognita of three plant residues (broccoli, melon and tomato) at three different temperatures $\left(20,25\right.$ and $\left.30^{\circ} \mathrm{C}\right)$. A strong significant reduction of the root-knot nematode was observed at the highest temperature, probably due to the increase of ammonia concentration.

Since the composting process could lead to the decomposition of nematicide compounds resulting in a non suppressive effect of mature compost (Cayuela et al., 2008) the combination of two amendments, COP and CM, or VOP and $\mathrm{CM}$ could result in a higher nematode suppression and a higher crop yield compared to single application, as previously observed on tomato by Marull et al. (1997). Therefore the mixtures of these materials could be suggested to optimize the beneficial effects of each amendment either for nematode control and plant growth.

\section{References}

ABAWI, G. S., WIDMER, T. L. (2000): Impact of soil health management practices on soilborne pathogens, nematodes and root diseases of vegetable crops. Appl. Soil Ecol., 15: 37 - 47. DOI: 10.1016/S0929-1393(00)00070-6

ABAwI, G. S., Thurston, H. D. (1994): Effects of organic mulches, soil amendments, and cover crops on soilborne 
plant pathogens and their root diseases: a review. In: Thurston, H. D., Smith, M., Abawi, G. S., Kearl, S. (Eds) Tapado, slash/mulch: How farmers use it and what researchers know about it. Cornell University, Ithaca, NY, pp. $89-99$

AKHTAR, M. (1997): Current options in integrated management of plant-parasitic nematodes. Integ. Pest Manag. Reviews, 2: 187 - 197. DOI: 10.1023/A:1018409303298

Berkelmans, R., Ferris, H., TENUTA, M., VAN Bruggen, A. H. C. (2003): Effects of long-term crop management on nematode trophic levels other than plant feeders disappear after 1 year of disruptive soil management. Appl. Soil Ecol., 23: 223 - 235. DOI: 10.1016/S9291393(03)00047-7

Bernal, M. P., Paredes, C., SÂnchez-Monedero, M. A., Cegarra, J. (1998): Maturity and stability parameters of compost prepared with a wide range of organic wastes. Biores. Technol., 63: 91 - 99. DOI: 10.1016/S09608524(97)00084-9

Bernal, M. P., Alburquerque, J. A., Moral, R. (2009): Composting of animal manures and chemical criteria for compost maturity assessment. A review. Biores. Technol., 100: 5444 - 5453. DOI: 10.1016/j.biortech.2008.11.027

BREMNER, J. M., KEENEY, D. R. (1965): Steam distillation methods for determination of ammonium, nitrate and nitrite. An. Chim. Acta, 32: 485 - 495

BREMNER, J. M. (1996): Nitrogen-total. In: Methods of Soil Analysis Part-3 Chemical Methods. Soil Science Society of America, Book series n. 5: 1089 - 1108

Briar, S. S., Grewal, P. S., Somasekhar, N., Stinner, D., Miller, S. A. (2007): Soil nematode community, organic matter, microbial biomass and nitrogen dynamics in field plots transitioning from conventional to organic management. App. Soil Ecol., 37: 256 - 266. DOI: 10.1016/ j.apsoil.2007.08.004

Bulluck, L. R., Brosius, M., Evanylo, G. K., Ristaino, J. B. (2002): Organic and synthetic fertility amendments influence soil microbial, physical and chemical properties on organic and conventional farms. App. Soil Ecol., 19, 147 - 160. DOI: 10.1016/S929-1393(01)00187-1

Cabrera, F., Martín-Olmedo, P., López, R., Murillo, J. M. (2005): Nitrogen mineralization in soils amended with composted olive mill sludge. Nut. Cycl. Agroecosys., 71: 249 - 258. DOI: 10.1007/s10705-004-6373-3

Castillo, P., Nico, A. I., Azcon-Aguilar, C., Del Rio Rincon, C., Calvet, C., Jimenez-Diaz, R. M. (2006): Protection of olive planting stocks against parasitism of root-knot nematodes by arbuscular mycorrhizal fungi. Plant Pathol., 55: 705 - 713. DOI: 10.1111/j.13653059.2006.01400.x

Cayuela, M. L., Millner, P. D., Meyer, S. L. F., Roig, A. (2008): Potential of olive mill waste and compost as biobased pesticides against weeds, fungi, and nematodes. Sc. Tot. Environ., 399: 11 - 18. DOI: 10.1016/j.scito tenv.2008.03.031

CCQC - CALIFORNIA COMPOST QUALITY COUNCIL (2001): Compost maturity Index. Technical Report. June 2001 from http://www.ccqc.org
Ciccarese, F., Paciolla, C., Sasanelli, N., Ciccarese, A., De Leonardis, S., Sciacovelli, M. (2008): Can the ozone be used in the control of plant diseases? In Abstracts of $10^{\text {th }}$ Annual Congress FISV (Federazione Italiana Scienza della Vita), September 24 - 27. Riva del Garda, Italy, pp. 18

CoOLEN, W. A. (1979): Methods for the extraction of Meloidogyne spp. and other nematodes from roots and soil. IN: LAMBERTI, F., TAYLOR, C. E. (Eds) Root-kont nematodes (Meloidogyne species), Systematics, Biology and Control. London, UK: Academic Press, pp. 317 - 329

D'ADDABBo, T., SASANElli, N. (1996): Effect of olive pomace soil amendment on Meloidogyne incognita. $\mathrm{Ne}$ matol. Mediterr., 24: $91-94$

D’Addabbo, T., SAsanelli, N., LAmberti, F., CARElla, A. (2000): Control of root-knot nematodes by olive and grape pomace soil amendments. Acta Hort., 532: 53 - 57

D’Addabbo, T., Sasanelli, N., Lamberti, F., Greco, P., CARella, A. (2003): Olive pomace and chicken manure amendments for control of Meloidogyne incognita over two crop cycles. Nematropica, 33(1): $1-8$

D’Addabbo, T., Papajova, I., SASAnelli, N., Radicci, V., RENČO, M. (2011): Suppression of root-knotnematodes in potting mixes amended with different composted biowastes. Helminthologia, 48: 278 - 287. DOI: 10.2478/S11687-011-0039-X

De Neve, S., Pannier, J., Hofman, G. (1996): Temperature effects on $\mathrm{C}$ - and N-mineralization from vegetable crop residues. Plant Soil, 181: 25 - 30. DOI: 10.1007/BF 00011288

DROUINEAU, G. (1942): Dosage rapide du calcaire actif de sols. Ann. Agron. Vol.12

Gamliel, A., Austerweil, M., Kritzman, G. (2000): Non-chemical approach to soilborne pest managementorganic amendments. Crop Prot., 19: 847 - 853. DOI: 10.1016/S0261-2194(00)00112-5

Gessa, C., Ciavatta, C. (2000): Complesso di scambio. In: Franco Angeli (Ed) Methods of Chemical Analysis of the soil. Italian Ministry of Agriculture and Forestry. Rome, Italy (In Italian)

GoMmERS, F. J. (1981): Biochemical interactions between nematodes and plants and their relevance to control. Helminthol. Abst. Series B, Plant Nematol., 50: 9 - 24

Grainge, M., AhMED, S. (1988): Handbook of Plants with Pest-Control Properties. $1^{\text {th }}$ Edition, New York, WILEY J. \& Sons (Eds). $470 \mathrm{pp}$.

HU, C., QI, Y.C. (2010): Abundance and diversity of soil nematodes as influenced by different types of organic manure. Helminthologia, 47: 58 - 66. DOI: 10.2478/ s1 1687-010-0009-8

HUSSEY, R. S., BARKER, K. S. (1973): A comparison of methods of collecting inocula of Meloidogyne spp. including a new technique. Plant Dis., 57: 1025-1028

Iglesias-Jimenez, E., Perez-Garcia, V. (1992): Determination of maturity indices for city refuse composts. $\mathrm{Agr}$. Ecosyst. Environ. 38: 331 - 343. DOI: 10.1016/01678809(92)90154-4

Indorante, S. J., Follmer, R., Hammer, R. D., KoEnig, 
P. G. (1990): Particle-size analysis by a modified Pipette procedure. Soil sci. Soc. Am. J., 54, 560 - 563

ITALIAN OFFICIAL METHODS FOR FERTILIZER ANALYSIS. (2002): Official Bulletin n. 220 published on 19-9-2002, Rome, Italy.

KAPLAN, M., NOE, J. P. (1993): Effects of chicken-excrement amendments on Meloidogyne arenaria. J. Nematol., 25(1): $71-77$

Loeppert, R. H., SuArez, D. L. (1996): Carbonate and gypsum. In: Method of Soil Analysis Part-2 Chemical Methods. Soil Science Society of America, $2^{\text {nd }}$ Ed. Agron. Monogr. 9. 437 - 444

López-Piñeiro, A., Albarrán, A., Rato Nunes, J.M., BARRETO, C. (2008): Short and medium term effects of two-phase olive mill waste application on olive grove production and soil properties under semiarid mediterranean conditions. Biores. Technol. 99 : 7982 - 7987. DOI: 10.1016/j.biortech.2008.03.051

LóPez-PÉrez, J.-A., Roubtsova, T., Ploeg, A. (2005): Effect of three plant residues and chicken manure used as biofumigants at three temperatures on Meloidogyne incognita infestation of tomato in greenhouse experiments. $J$. Nematol., 37(4): 489 - 494

MAI, W.F. (1985): Plant-parasitic nematodes: their threat to agriculture. In: An Advanced Treatise on Meloidogyne. Vol. I, Biology and Control. SASSER J.N. \& CARTER C.C. (Eds) North Carolina State Univ. Graphics, Raleigh, N.C., U.S.A., pp. $11-17$

Maistrello, L., Vaccari, G., Sasanelli, N. (2010): Effect of chestnut tannins on the root-knot nematode Meloidogyne javanica. Helminthologia, 47: 48 - 57. DOI: 10.2478/s11687-010-0008-9

Marull, J., Pinochet, J. (1991): Host suitability of Prunus rootstock to four Meloidogyne species and Pratylenchus vulnus in Spain. Nematropica, 21:185 - 195

MARUll, J. J., PINOCHET, RodRIGUEZ-KABANA, R. (1997): Agricultural and municipal compost residues for control of root-knot nematodes in tomato and pepper. Compost Sci. Util., 1: 6-15

MinISTERIAL DECREE, n. 86 (1999): Adoption of the Code of Good Agricultural Practice. Official Journal No. 102, S.O. n. 86 published on $4^{\text {th }}$ May, 1999 - Italian Republic MINISTERIAL DECREE, n. 75 (2010): Reorganization and revision of regulations on fertilizers in accordance with art. 13 of the Law of 7 July 2009, n. 88. Official Journal No. 121, May 26, 2010 - Italian Republic

Nahar, M. S., Grewal, P. S. , Miller, S. A., Stinner, D., Stinner, B. R., Kleinhenz, M. D., WszelaKi, A., DoOHAN, D. (2006): Differential effects of raw and composted manure on nematode community and its indicative value for soil microbial, physical and chemical properties. App. Soil Ecol., 34: 140 - 151. DOI: 10.1016/j.apsoil.20 06.03.011

Nelson, D. W., Sommers, L. E. (1996): Total Carbon, Organic Carbon and Organic Matter. In: Method of Soil Analysis Part-3 Chemical Methods. Soil Science Society of America, Book series n. 5: 995 - 996.

Nico, A. I., JimÉnez-DìAZ, R. M., CAstillo, P. (2004): Control of root-knot nematodes by composted agro-indus268 trial wastes in potting mixtures. Crop Prot., 23: 581 - 587. DOI: 10.1016/j.cropro.2003.11.005

OKa, Y., Koltai, H., Bar-Eyal, M., Mor, M., Sharon, E., Chet, I., SpIEgel, Y. (2000): New strategies for the control of plant parasitic nematodes. Pest Manag. Sci., 56: 983 - 988. DOI: 10.1002/1526-4998(200011)

Olsen, S. R., SOMMERS, L. E. (1982): Phosphorus. In: Method of Soil Analysis Part-2 Chemical Methods. Soil Sci. Soc. of America, $2^{\text {nd }}$ Ed. Agron. Monogr. 9: 403 - 430. RENČO, M., D’AdDABBo, T., SASANELli, N., PAPAJOVÁ, I. (2007): The effect of five composts of different origin on the survival and reproduction of Globodera rostochiensis. Nematology, 9(4): 537 - 543. DOI: 10.1163/156854107781487260 Renčo, M., SAsanelli, N., Šalamún, P. (2009): The effect of two compost soil amendments, based on municipal green and penicillin production wastes, on plant parasitic nematodes. Helminthologia, 46: 190 - 197. DOI: 10.2478/s11687-009-0035-6

RenČO, M., SASANElli, N., KovÁČIK, P. (2011): The effect of soil compost treatments on potato cyst nematodes Globodera rostochiensis and Globodera pallida. Helminthologia, 48: 184 - 194. DOI: 10.2478/s11687-011-0027-1 RenČO, M., SASANElli, N., PAPAJOVÁ, I., Maistrello, L. (2012): The nematicidal effect of chestnut tannin solutions on the potato cystnematode Globodera rostochiensis (Woll.) Behrens. Helminthologia, 49: 108 - 114. DOI: 10.2478/s11687-012-0022-1

RhoAdes, J. D. (1996): Salinity: Elecrical Conductivity and Total Dissolved Solids. In: Method of Soil Analysis Part-3 Chemical Methods. Soil Sci. Soc. of America, Book series n. 5: $417-435$

Rivera, L., Aballay, E. (2008): Nematicide effect of various organic soil amendments on Meloidogyne ethiopica Whitehead, 1968, on potted vine plants. Chil. J. Agric. Res., 68: 290 - 296

RODRIGUEZ-KABANA, R. (1986): Organic and inorganic nitrogen amendments to soil as nematode suppressants. $J$. Nematol., 18: 129 - 135

Rodriguez-KabAna, R., PinOChet, J., CAlvet, C. (1992): Olive pomace for control of plant-parasitic nematodes. Nematropica, 22: 149 - 158

Rodriguez-Kabana, R., Estaun, J. Pinochet, And MARFA, O. (1995). Mixtures of olive pomace with different nitrogen sources for the control of Meloidogyne spp. on tomato. J. Nematol., 27 (4S): 575 - 584

Rodriguez, J. C., SHAW, N., CANTliffe, D. J., KARChi, Z. (2005): Nitrogen fertilization schedu-ling of hydroponically grown "galia" muskmelon. Proc. Fla. State Hort. Soc, 118 : $106-112$

Roig, A., Cayuela, M. L., Sanchez-Monedero, M. A. (2006): An overview on olive mill wastes and their valorisation methods. Waste Manag., 26: 960 - 969. DOI: 10.1016/j.wasman.2005.07.024

RYAN, J., EsTEFAN, G., RASHID, A. (2001): Soil and plant analysis. Laboratory manual. II ED. published by the International Centre for Agricultural Research in the Dry Areas (ICARDA) and the National Agricultural Research Centre (NARC). Available from ICARDA, Aleppo Syria. 
SAIDI, N., KouKI, S., M'HIRI, F., Jedidi, N., MAHrouK, M., HASSEN, A., OuZARI, H. (2009): Microbiological parameters and maturity degree during composting of Posidonia oceanica residues mixed with vegetable wastes in semiarid pedo-climatic condition. J. Environ. Scie., $211452-$ 1458. DOI: 10.1016/S1001-0742(08)62439-0

SASANElli, N., D’ADDABBO, T. (1993): Potential application of Ruta graveolens for controlling Meloidogyne javanica on sunflower. Russ. J. Nematol., 1: $117-120$

SASANELli, N. (1994): Tables of Nematode-patogenicity. Nematol. Mediterr., 22: $153-157$

SASANELli, N., GRECO, N. (2000): Formulation of a model to relate nematode populations with exposure times to a range of temperatures. Acta Hort., 532: 131 - 135

Sasanelli, N., D’Addabbo, T., Convertini, G., Ferri, D. (2002): Soil Phytoparasitic Nematodes Suppression and Changes of Chemical Properties Determined by Waste Residues from Olive Oil Extraction. In: Proceedings of $12^{\text {th }}$ ISCO Conference, May $26-31,2002$. Beijing, China. Vol. III: $588-592$

Sasanelli, N., Anton, A., D’Addabbo, T., TAKacs, T. (2007): Nematicidal properties of leaf extracts of Ruta graveolens inoculated with arbuscular mycorrhizal fungi. Russ. J. Nematol., 15: $65-73$

Sasanelli, N., Ciccarese, F., PapajovÁ, I. (2008): Aphanocladium album by via sub-irrigation in the control of Pyrenochaeta lycopersici and Meloidogyne incognita on tomato in a plastic-house. Helminthologia, 45: $137-142$. DOI: 10.2478/s11687-008-0027-y

Sasanelli, N., Anton, A., TAKacs, T., D’AddabBo, T., BIRÒ, I., MALOV, X. (2009): Influence of arbuscular mycorrhizal fungi on the nematicidal properties of leaf extracts of Thymus vulgaris L. Helminthologia, 46: $230-$ 240. DOI: 10.2478/s11687-009-0043-6

SAViozzi, A., LeVi-Minzi, R., CARdelli, R., Biasci, A., RIFFALDI, R. (2001): Suitability of moist olive pomace as soil amendment. Water Air Soil Pollut., 128: 13 - 22. DOI: 10.1023/A:1010361807181

SENESI, N. (1989): Composted Materials as Organic Fertilizers. Sci. Total Environ., 81/82: 521 - 542

Stanford, G., SMith, S. J. (1972): Nitrogen Mineralization Potentials of Soils. Soil Sci. Soc. Amer. Proc., 36: 465 $-472$
STIRLING, G. R. (1991): Mode of action of organic amendments against nematodes. In: Biological Control of Plant Parasitic Nematodes. Progress, Problems and Prospects. C.A.B. INTERNATIONAL (Eds). London, U.K., pp. $170-180$ TAMIETTI, G., VALENTINO, G. (2000): Effectiveness of soil solarization against soil borne plant pathogens and weeds in Piedmont (Northern Italy). Acta Hort., 532: 151 - 156

TAYLOR, A. L., SASSER, J. N. (1978): Biology, identification and control of root-knot nematodes (Meloidogyne species). Department of Plant Pathology, North Carolina State University, and U. S. Agency for International Development, Raleigh, N.C., U.S.A., pp. 111

TESTER, C. F. (1990): Organic amendment effects on chemical and physical properties of a sandy soil. Soil Sci. Soc. Am. J., 65: $1284-1292$

Thomas, G. W. (1996): Soil pH and Soil Acidity. In: Method of Soil Analysis Part-3 Chemical Methods. Soil Sci. Soc. of America, Book series n. 5: 487 - 488

Tuamos, E. C., Polymnia, P. A., Tuamos, S. E. (2000): Implementation of soil solarization in Greece: Conclusions and suggestions. Crop Prot., 19: 843 - 846. DOI: 10.1016/S0261-2194(00)00132-0

TRUDGILL, D. L., BLOK, V. C. (2001): Apomictic polyphagous root-knot nematodes: exceptionally successful and damaging biotrophic root pathogens. Annu. Rev. Phytopathol., 39: 53 - 57. DOI: 10.1146/annurev.phyto.39.1.53 US TMECC (1997): Test methods for the examination of composting and compost. The US Composting Council. $1^{\mathrm{TH}}$ ED. The United States Composting Council, Amherst, Ohio (U.S.A.)

USDA, SoIL SuRveY Division STAFF (1995): Soil survey manual - Soil conservation service - U. S. Department of Agriculure. Handbook 18.

VANNACCI, G., GULlinO, M. L. (2000): Use of biological agents against soil borne pathogens: Results and limitations. Acta Hort., 532: $79-87$

Whitmore, A. P. (2007): Determination of the mineralization of nitrogen from composted chicken manure as affected by temperature. Nut. Cycling Agroeco., 77: 225 232. DOI: $10.1007 / \mathrm{s} 10705-006-9059-1$

Zucconi, F., Forte, M., Monaco, A., De Bertoldi, M. (1981): Biological evaluation of compost maturity. BioCycle, 22: 4: $27-35$ 